\title{
The role of hydropower in electric power integration of Asian countries
}

\author{
Lev Belyaev, Vladimir Savelyev, and Lyudmila Chudinova* \\ Melentiev Energy Systems Institute, Siberian Branch of the Russian Academy of Sciences, \\ Department of Electric Power Systems. 130, Lermontov str., Irkutsk, Russia
}

\begin{abstract}
The possible role of hydropower plants in formation and operation of interstate power pools is described based on the generalization of the world experience. Peculiarities of the influence of hydropower on development of interstate electric ties in this part of the world and potential effects are showed on the example of Central and Northeast Asia.
\end{abstract}

\section{Introduction}

Hydropower plants (HPPs) as sources of renewable energy produce cheap and environmentally friendly electricity and have high regulating and maneuvering capabilities. Pumped storage power plants (PSPPs) are the most inexpensive high-power energy storage. This fact determines a special role of hydropower engineering in development of interstate electric ties (ISETs) and formation of interstate power pools (ISPPs) in many regions of the world. In particular, the construction of HPPs contributed to the creation of ISPPs in the territories of North, Central and South America, Scandinavia, Central and South Africa [1]. Hydroelectric power plays an important role in the projects of integration of the electric power sectors of the countries of Central, Northeast, Southeast and South Asia. Table 1 characterizes the hydropower potential and the state of its usage in these regions [2-4, etc.).

Construction of HPPs and PSPPs within the interstate power pool replaces fossil-fueled power plants from their energy balances, and promotes the development of renewable energy sources (RESs), mitigating the environmental problems in the participating countries. The regulated hydropower plants maintain uniform operation of nuclear power plants and can compensate for natural fluctuations in electricity production of solar, wind and other renewable energy sources, improving thus reliability and efficiency of power supply in power pools. In some cases, construction of ISPPs contributes to solving the problems of using water and hydropower resources of transboundary water bodies (rivers and lakes).

On the other hand, the increasing scales of ISPP as a unified power system makes it possible to increase the installed capacities of hydropower plants and improve their cost effectiveness.

The current problems and possible directions for the development of interstate power pools in Central and Northeast Asia are considered below in the context of the impact of hydropower of countries with a high potential of hydropower resources on them.

${ }^{*}$ Corresponding author: chudinova@isem.irk.ru 
Table 1. State of hydropower resources.

\begin{tabular}{|l|c|c|c|c|c|}
\hline \multicolumn{1}{|c|}{ Region } & $\begin{array}{c}\text { Installed } \\
\text { capacity } \\
\text { (including } \\
\text { pumped } \\
\text { storage) in } \\
2016, \mathrm{GW}\end{array}$ & $\begin{array}{c}\text { Generation } \\
\text { in } 2016, \\
\text { TWh }\end{array}$ & $\begin{array}{c}\text { Gross } \\
\text { theoretical } \\
\text { capability, } \\
\text { TWh/year }\end{array}$ & $\begin{array}{c}\text { Technically } \\
\text { exploitable } \\
\text { capability, } \\
\text { TWh/year }\end{array}$ & $\begin{array}{c}\text { Current } \\
\text { utilization }\end{array}$ \\
\hline World total & 1239.5 & 4102 & 43378 & 15517 & $26 \%$ \\
\hline South America & $161.1(1.0)$ & 709 & 7893 & 2807 & $25 \%$ \\
\hline North and & & & & & \\
Central America & $200.9(22.6)$ & 702 & 7601 & 1842 & $38 \%$ \\
\hline Europe & $223.0(50.5)$ & 595 & 3129 & 1199 & $50 \%$ \\
\hline Africa & $33.6(3.4)$ & 106 & 4380 & 1484 & $7 \%$ \\
\hline Asia and Pacific & $620.9(72.2)$ & 1990 & 20375 & 8185 & $24 \%$ \\
including: & & & & & \\
Afghanistan & 0.442 & 1.17 & 394.5 & 88 & $1 \%$ \\
China & $332.11(26.7)$ & 1180.7 & 6083 & 2474 & $48 \%$ \\
Iran & $11.278(1.0)$ & 18.2 & 448 & 179 & $10 \%$ \\
Japan & $50.035(27.6)$ & 92 & 718 & 135.8 & $68 \%$ \\
Kazakhstan & 2.372 & 9.27 & 198.6 & 61.9 & $15 \%$ \\
Korea, North & 5.000 & 12.040 & 50 & $>26.0$ & $46 \%$ \\
Korea, South & 6.738 & 6.622 & 51.8 & 26.4 & $25 \%$ \\
Kyrgyzstan & 3.091 & 13.32 & 163 & 99 & $13 \%$ \\
Mongolia & 0.026 & 0.059 & 56.2 & 22 & $0 \%$ \\
Pakistan & 7.115 & 34.272 & $>475$ & 219 & $16 \%$ \\
Russia, including: & $51.45(1.4)$ & 186.6 & 2395 & 1670 & $11 \%$ \\
Sibir & 26.5 & 103.2 & 993 & 757 & $14 \%$ \\
Far East & 5.8 & 18.6 & 1009 & 684 & $3 \%$ \\
Tajikistan & 5.19 & 16.9 & 527 & 317 & $5 \%$ \\
Turkmenistan & 0.001 & 0.003 & 23.9 & 4.8 & $0 \%$ \\
Uzbekistan & 1.889 & 10.59 & 88.5 & 27.4 & $39 \%$ \\
\hline
\end{tabular}

\section{Central Asia}

Central Asia includes 6 countries: Iran, Kazakhstan, Kyrgyzstan, Tajikistan, Turkmenistan and Uzbekistan. In addition, as will be shown below, Afghanistan and Pakistan, geographically belonging to South Asia, are closely related with them in the field of electricity supply and prospects for the establishment of a regional ISPP.

The countries that previously were members of the interconnected power system of Central Asia of the Unified Power System of the USSR play an important role in the electric power integration of Central Asia countries. After its disintegration, these countries created their own ISPP - Central Asian Power System (CAPS) [1]. This pool allowed preservation of all the advantages of energy integration that were achieved owing to the centralized management of development and functioning of the electric power industry of the Soviet Union. In particular, this made it possible to use rationally diverse energy resources of these countries: coal in Kazakhstan, oil and natural gas in Turkmenistan, hydropower in Tajikistan and Kyrgyzstan. Besides, the unified integrated water and energy complex was created and managed from the joint center in Uzbekistan. It ensured the balance of seasonal fluctuations in electricity demand and water requirements for irrigation purposes with fluctuations in its inflow to the HPP reservoirs. 
However, the political and trade contradictions between individual Central Asia countries ended in the exit of Turkmenistan first (2003) and then Uzbekistan (2009) from the electric ring. This situation gave rise to the problems of meeting the irrigation requirements by the Tajik and Kyrgyz hydropower plants in Uzbekistan, on the one hand, and, on the other, maintaining the electricity balances in Tajikistan and Kyrgyzstan. The problem is that the loss of hydro energy in the summer season that is caused by additional water discharge because of the low electricity demand leads to its shortage in the winter season $[5,6]$. These hydropower losses amounted to about 6 TWh per year. In addition, the construction of the Rogun HPP on the Vakhsh river and the Sangtuda HPP on the Naryn was halted.

To date, the situation in the electric power industry and water management of the region has changed significantly, in particular, owing to the active participation of the UN and the world financial system (World, Asian, Islamic and other banks and funds) [7, 8]. The International Conference under the auspices of the United Nations "Water for Life", held in 2015 in Dushanbe [5], which highlighted the importance of these problems for the socioeconomic development of the countries of the region, also served to this change.

At the end of 2017, Tajikistan and Uzbekistan proposed restoration of the unified regional power system, taking into account, in particular, the need to solve the problems of electricity supply to neighboring Afghanistan [8]. This makes it possible to raise the issue of creating interstate electric lies between CAPS, Afghanistan and Pakistan once again.

The project of expanding the CAPS borders due to the availability of unused seasonal hydropower in the late 1990 s - early 2000 s, as well as the potential for a significant increase in its production at the new HPPs was developed on the initiative of the World Bank for Development ("CASA-1000" project) [5,6] . Initially, the project envisaged completion of the construction of the Rogun HPP and the Sangtuda HPP and in addition, construction of new hydropower plants (the Vakhsh cascade in Tajikistan, the Kambarata HPPs and the Toktogul cascade in Kyrgyzstan). In this case, the export potential of these countries could increase to almost $40 \mathrm{TWh}$ by 2025 . For the delivery of this electricity to Afghanistan and Pakistan, it was planned to build transboundary transmission lines (TBTLs) with a voltage of $500 \mathrm{kV}$ : "Kyrgyzstan-Tajikistan-Afghanistan" with a converter substation in Kabul and the direct current TBTL to Peshawar (Pakistan). The project also included proposal about construction of a $500 \mathrm{kV}$ TBTL from Turkmenistan to Iran.

The implementation of CASA-1000 is the first stage in creating the Central Asia-South Asia Regional Electricity Market (CASAREM) (Fig. 1) [9]. The project can promote the development of electricity trade between the countries of the two regions of South and Central Asia and involves the export of excessive summer electricity from Tajikistan and Kyrgyzstan to Pakistan. In this case, Afghanistan can make a profit as an electricity transporter.

In total, there are plans to create an asynchronized power system of 6 South and Central Asia countries (Turkmenistan, Uzbekistan, Tajikistan, Kyrgyzstan, Afghanistan and Pakistan) beyond 2020, based on the existing and planned AC electric networks in Afghanistan.

In addition, through the power systems of India Pakistan is developing ISETs with the power systems of the South Asia countries belonging to the South Asian Association for Regional Cooperation (SAARC).

Thus, the main incentive for interstate energy integration of the countries of Central and South Asia is the use of the currently unclaimed electricity generation at HPPs, the possibilities of its additional increase at new HPPs (under construction and planned), and the expansion of natural gas export for its use at export-oriented thermal power plants (TPPs). 


\section{Northeast Asia}

This Asian region includes 6 countries (China, the Republic of Korea, the DPRK, Japan, Mongolia and Russia). At the same time, the electric power integration within the framework of the future interstate power pool of Northeast Asia mainly concerns only the North and Northeast China and the eastern regions of Russia

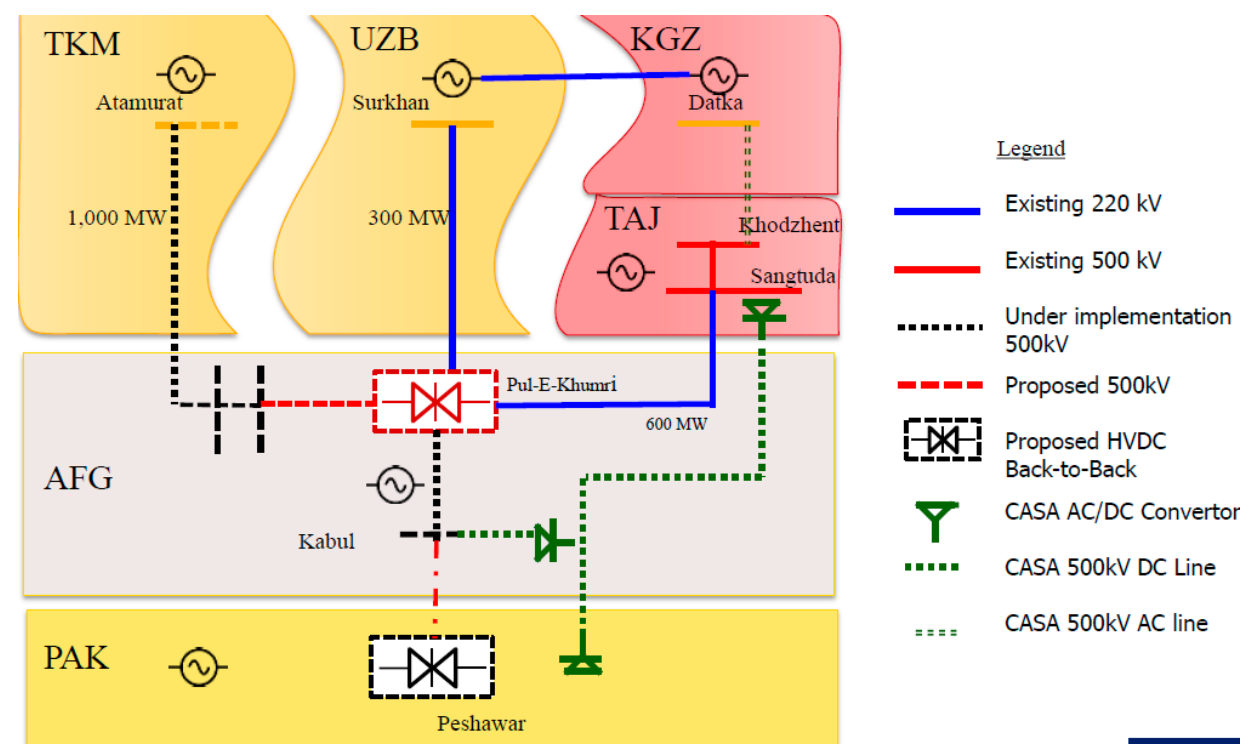

Fig. 1. Central Asia - South Asia Regional Electricity Market (CASA - 1000 and TUTAP).

(Eastern Siberia and the Russian Far East). Interest in the development of ISETs and the establishment of ISPP NEA has a long history. However, despite favorable conditions [10] and high potential efficiency [11], its formation is still at the stage of the pre-feasibility study. In all related research, special attention is paid to hydropower.

This is due to a number of reasons. First of all, the two countries (China and Russia) have the greatest potential in the world for hydropower resources (Table 1). Japan and the DPRK also have great hydro potential. Only the Republic of Korea and Mongolia are poor in hydropower.

Further, some countries of the region have faced acute environmental problems and are forced to actively develop renewable energy.

Then, the countries under consideration are characterized by different conditions for hydropower development in the long view: the rates of economic development and the growth of electricity consumption, as well as the need for new power plants, the structure of generating capacities and the fuel balance of TPPs.

And finally, different countries have different investment opportunities and pursue their own policy in construction of HPPs with a long payback period.

It should also be noted that there is no generally accepted project for the ISET development in the region and the establishment of the regional ISPP of Northeast Asia. Currently, the main focus is on the choice of priority interstate electric ties.

All these factors influence the HPP participation in the electric power integration of individual countries in the region and the prospects for their hydropower development, taking into account external electric ties. This is especially true of the eastern regions of Russia (Fig. 2).

Let us dwell on the specific features of hydropower development in the NEA countries and their possible role in the formation of the regional ISPP. 
As can be seen from Table 1, Japan has practically utilized its hydropower resources, including the construction of pumped storage power plants. Their rapid development until 2011 was necessitated by the need to level the electricity production of intensively constructed nuclear power plants. After the accident at the Fukushima-1 nuclear power plant and decommissioning of practically all nuclear power plants in the country, the available capacities of PSPPs provided opportunities for the large-scale construction of

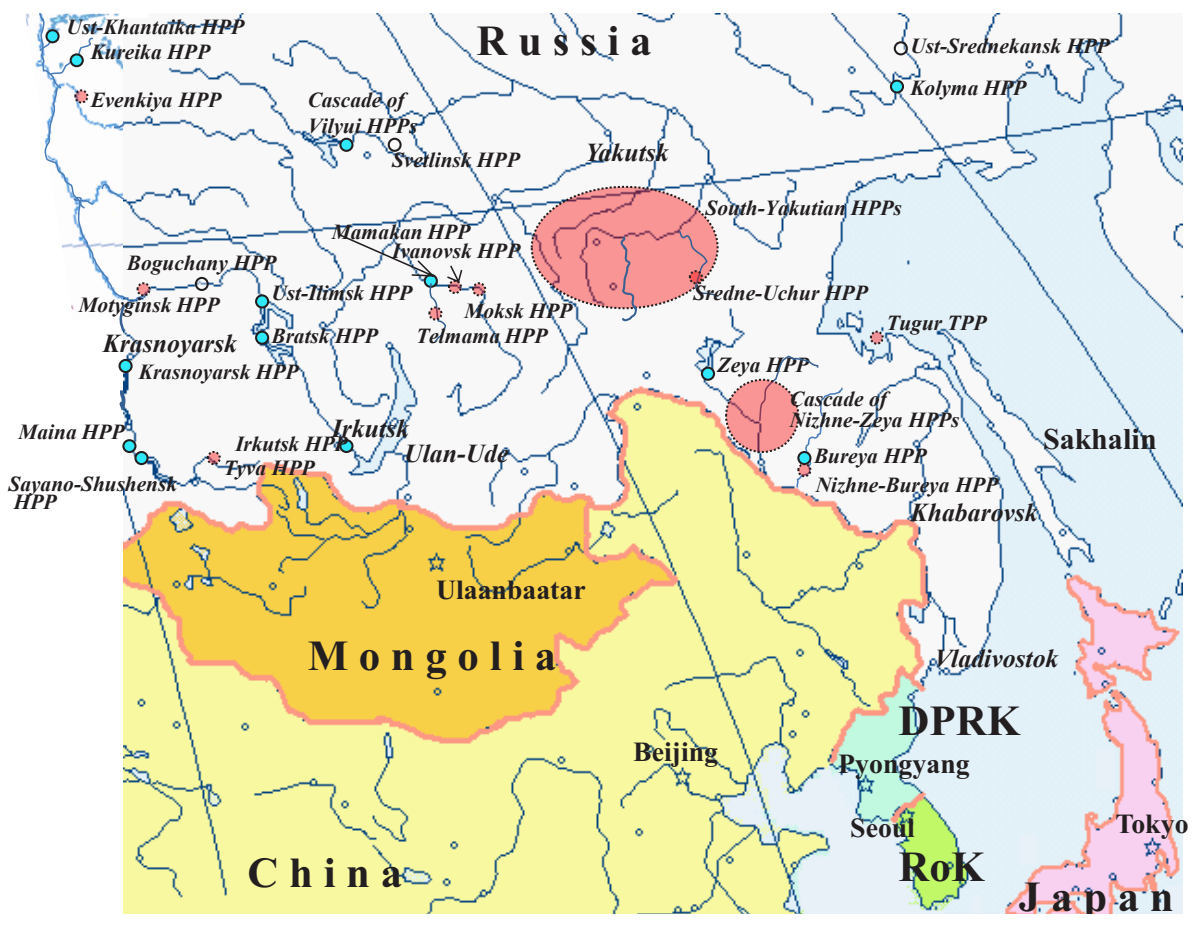

Fig 2. Map of hydropower resources development in Eastern Russia and directions of ISETs with NEA countries.

solar power plants. The need of this country to develop interstate electric ties with the eastern regions of Russia rich in hydropower resources is explained at the present stage by the necessity of increasing the import of environmentally clean electricity. In this case its generation by thermal power plants in Japan will decrease, which will allow the environmental problems to be solved and the dependence on the import of hydrocarbon fuels to be overcome. Therefore, Japan is interested in importing clean electricity from Russia.

The Republic of Korea experiences similar problems and needs in the development of interstate electric ties in the context of hydropower development.

In the DPRK, the hydropower plants, in the absence of the possibility of using other energy resources, in particular coal, are practically the only source of electricity. Part of their generation was even exported to the Liaoning province of Northeast China. Therefore, this country is interested in diversification of electric power sources, which, if the political situation changes, include ISETs with China and Russia.

Mongolia's electric power industry currently relies on coal-fired cogeneration plants, leveling the electric load curves, in particular, due to the reverse TBTL from the Gusinoozerskaya TPP to Buryatia. In order to cover the need for maneuvering capacities, 
the country plans to construct several hydropower plants on the Selenga river and its tributaries. These plans aroused sharp criticism of the Russian environmental community because of the possible adverse impact on the ecosystem of lake Baikal. However, this issue is ambiguous. Based on the current world practice, the use of water resources of the transboundary rivers is, in principle, allowed. However, in this case we are talking about the use of water reserves of the object of global significance according to UNESCO classification. For a time, the problem of power shortage in Mongolia can be solved by increasing exports from the Gusinoozerskaya TPP. But this is not a cardinal decision. Therefore, additional research is needed to resolve the contradiction that has arisen.

Another line of interstate electric ties between Russia and Mongolia consists in the construction of the TBTL from the Sayano-Shushenskaya HPP to the Altai-Uliastai power system in the west of the country. This ISET will make it possible to use the locked capacity of the Sayano-Shushenskaya HPP, ensure the development of the mining industry in this power system and the creation of the unified national power system of Mongolia.

People's Republic of China. The role of this country in the electric power integration both in the Northeast region and the whole Asian continent is largely decisive because of its leading position in their economic development.

China is ranked first in the world in electricity production and consumption, has a great investment, construction and technological potential. At the same time it is engaged in intensive hydroelectric construction and is ready to render any assistance in the construction of new HPPs in other regions of the world, including Russia.

The level of practical use of hydropower potential in China in 2016 reached $48 \%$. The constructed "Three Gorges" HPP with an installed capacity of $22.4 \mathrm{GW}$ is the world's largest HPP. The construction of another giant hydropower plant Baihetan with a capacity of $16 \mathrm{GW}$, an average annual output of 60.24 billion $\mathrm{kWh}$ has been started.

In addition to solving domestic problems, the development of China's hydropower, in particular in the Yunnan province, promotes the development and functioning of interstate electric ties in Southeast Asia. The Yunnan province with its largest rivers Yangtze, Mekong and $\mathrm{Nu}$ is one of the richest world regions in hydropower resources [12]. In the province there are 128 hydropower objects with a total capacity of $16.5 \mathrm{GW}$. They can cover the increasing electricity consumption not only in the Southern power pool of China, but also in the whole Greater Mekong region. Thus, the hydropower industry of this province can contribute to the formation of the unified ISPP as an Asian part of the Eurasian electric power space [13].

It should be noted that China reached a very high technological and economic level in other branches of the electric power industry and the electrical engineering. The manufacture of relatively cheap equipment with ultrasupercritical steam parameters for thermal power plants, electric grid equipment with a voltage of $1100 \mathrm{kV} \mathrm{AC}$ and $\pm 800 \mathrm{kV}$ DC are the vivid examples. The wind and solar power engineering are also actively developing in the country. This reduces the need and competitiveness of electricity imports from other countries of the region.

At the same time, the problem of developing interstate electric ties in the region and participation of China in this process remains relevant.

\section{Eastern regions of Russia}

Eastern Siberia and especially the Russian Far East, have the richest unused hydropower resources. They served as the basis for active hydropower construction in these areas in the 20th century. As a result, the unique Angara-Yenisei cascade of HPPs, Vilyuiskaya, Zeyskaya and Kolyma hydropower plants were constructed on the same rivers. This 
provided a high share of hydropower in the structure of generating capacities in IPS of Siberia and IPS of East. Meanwhile, the development of the hydropower potential of the eastern regions is still lagging behind its utilization in the European part of Russia.

As is shown in [14-16], currently the possibilities of hydropower construction in Russia and in its eastern regions have changed significantly due to a decreasing need for new sources of electricity, limited investment opportunities for the state and private companies, difficulties in economic development and development of natural resources of new territories, rise in the cost of HPP projects due to relocation of construction sites to remote, poorly developed territories, etc.

In these conditions, the development of interstate electric ties with neighboring countries, primarily East Asia, is of particular importance. Hydropower in the eastern regions of Russia can participate in expanding these ties in several directions (Fig. 2).

Firstly, there are many purely export projects for the construction of HPPs on the Siberian and Far-Eastern rivers in order to supply their electricity to China, Japan and the Korean peninsula $[9,10]$. In particular, the project of electricity exports to Japan from the HPPs of the South Yakutia hydropower complex [15].

Secondly, the hydropower plants in the eastern regions of Russia, which have large water reservoirs, primarily the Angara and Yenisei reservoirs, play an important role in the implementation of integration (systemic, synergetic) effects of the creation of ISPP NEA. In particular, this applies to the effect of the discrepancy in the seasons of the annual maximum loads, on the one hand, in IPS of Siberia and IPS of East, and, on the other hand, in the power systems of Japan, the Republic of Korea and North China. Realization of this effect makes it possible to considerably reduce the commissioning of generating capacities in these countries. At the same time, the fuel costs of thermal power plants will be saved and the emissions of pollutants into the environment will decrease.

Thirdly, the studies of the effectiveness of creating the ISPP NEA with the help of the mathematical model ORIRES revealed an additional integration effect associated with the use of the regulating capabilities of existing and new Siberian and Far Eastern hydropower plants at the control of its short-term operation conditions [11]. It consists in regulating the variable electricity production by renewable energy sources in neighboring countries.

On the whole, the studies of the Energy Systems Institute showed an important role of hydropower plants in the eastern regions of Russia and other countries in the formation of ISPP NEA and realization of the effects achieved in development of their hydropower engineering will be possible only with creation of the considered interstate interconnection. This conference demonstrated the interest in this ISPP.

The paper did not consider the impact of hydropower engineering on the development and operation of ISPPs in two other Asian regions: the South and Southeast regions. This issue requires special studies taking into account the existing and future electric ties of these regions with the countries of Central and Northeast Asia, as well as their role in formation of the Pan-Asian super power pool.

\section{References}

1. L.S. Beliayev, S.V. Podkoval'nikov, V.A. Savel'yev, L.Yu. Chudinova, Efficiency of Interstate Electric Ties (2008)

2. World Energy Resources, (2013). Available: http://www.worldenergy.org [Accessed 16 April 2016]

3. 2017 Hydropower Status Report, (2017). Available: https://www.hydropower.org [Accessed 20 August 2017]

4. Hydropower generation, (2014). Available: http://www.unesco.org [Accessed 30 August 2016] 
5. V. Pervukhin, Energy Policy, 1, 26-36 (2016)

6. R. Sharma, The Strategy of World Bank for Support of Energy Projects in Central Asia (2005)

7. Central Asia May Restore The Unified Energy System, (2017). Available: http://easttime.info [Accessed 20 May 2017]

8. Uzbekistan is interested in widening the Central Asian Ring, (2017). Available at: http://news.tj [Accessed 02 October 2017]

9. Central Asia - South Asia Regional Energy Trade (2014). Available: http://www.carecprogram.org [Accessed 02 October 2017]

10. L. Yu. Chudinova, S.V. Podkovalnikov, V.A. Savelyev, Studies on Russian Economic Development, 26 (4), 403-412 (2015)

11. S.V. Podkovalnikov, V.A. Savelyev, L.Yu. Chudinova, Energy, 5, 16-32. (2015)

12. T. Hennig, W. Wang, D. Magee, D. He, Water 2016, 8(10), 476 (2016)

13. V.A. Savelyev, L.Yu. Chudinova, Energetic, 7, 33-36 (2014)

14. L.S. Belyaev, N.I. Voropai, S.V. Podkovalnikov et al., Energy Policy, 1, .26-36. (2016)

15. L.S. Beliayev, S.V. Podkoval'nikov, V.A. Savel'yev, L.Yu. Chudinova, Procceedings of the Proceeding of 6th International Conference - Asian Energy Cooperation: Forecast and Realities ( Irkutsk, Russia, 2008)

16. Podkovalnikov S.V., Savelyev V.A., Chudinova L.Yu. Northeast Asia Energy Focus, 5 (3), 36-43 (2008) 